\title{
ASSESSING SUSTAINABILITY OF THE BAHABAD AQUIFER, CENTRAL IRAN
}

\author{
JAFARI, H.* - SHIRAFKAN, M. - BAGHERI, R. - KARAMI, G. H. \\ Faculty of Earth Sciences, Shahrood University of Technology, Shahrood, Iran \\ (phone: +98-23-3239-6007; fax: +98-23-3239-6007) \\ *Corresponding author \\ e-mail:h_jafari@shahroodut.ac.ir; phone: +98-91-3252-2107; fax: +98-23-3239-6007 \\ (Received 25 $5^{\text {th }}$ an 2018; accepted $25^{\text {th }}$ Apr 2018)
}

\begin{abstract}
Bahabad plain in central Iran contains vital groundwater resources, mainly used in agriculture. A well-field at the centre is discharging water for a further located mining and industrial site, results in a closed depression in water-table which divides the aquifer system into southern $(\mathrm{S})$ and northern $(\mathrm{N})$ zones. In this research, the sustainability of groundwater resources was evaluated by groundwater balance studies and safe yield analyses. The annual safe yields are estimated to be 22.3 and 3.7 million cubic meter (MCM) for the zones S and N, respectively. Based on balance studies, total annual abstractions (33.9 and 8.6 MCM, respectively) are greater than the total inputs, exceeding the safe yield, as well. So, the aquifer is over-exploited and groundwater is withdrawn from storage, declining water-table with an average rate of $50 \mathrm{~cm}$ annually. In contrast to the public perception of the major impact from well-field abstractions, this research clarifies the role of both industrial and agricultural abstractions in depletion of Bahabad aquifer. Therefore, safe yield must be considered in order to avoid further aquifer mining. It can be attained by decreasing industrial and agricultural abstractions and managing recharge to augment the aquifer storage, assuring the sustainability of the groundwater resources.
\end{abstract}

Keywords: aquifer mining, groundwater balance, over-exploitation, safe yield, Yazd

\section{Introduction}

The components of the water cycle are in a balancing state, naturally. However, human interventions, for example over-exploitation of the groundwater resources, disturb the balance leading to unfavorable impacts on the environment. Groundwater resources as a part of the water cycle are important in terms of water supply for different uses in many regions of the world, especially in arid and semi-arid areas where surface-water resources are not generally available. Over-exploitation (abstractions over than the recharge) of these vital resources results in "groundwater mining" which is followed by negative effects including depletion of aquifer storage, saline water intrusion, groundwater level decline, land subsidence and other environmental, economic and social problems (Brown et al., 1999). To avoid the problems, a proper management plan is required, assuring the sustainability of the groundwater resources. In this regard, concepts such as safe yield or sustainable yield were applied in groundwater managing strategies, generally restricting the withdrawals at values without negative impacts on the groundwater reservoirs. (Naik and Awasthi, 2003; Alley, 2004; Kalf and Woolley, 2005; Zhou, 2009). Safe yield of the groundwater system is defined as the amount of groundwater that can be exploited continuously without detrimental effects on the groundwater reservoirs (Central Groundwater Board, 1984). It includes all exploitable groundwater originating within the catchment (Naik and Awasthi, 2003).

To ensure sustainability, it is essential that the yield constraints is established based on the hydrological mass balance (Sophocleous, 2000). "The water balance is the 
perfect tool for a better understanding of the valuable groundwater resource which is nothing more than a material balance that accounts for all inputs, outputs and changes in storage within a system defined by prescribed boundaries" (Sophocleous, 2000).

Safe yield, as a feasible managing concept introduced by Naik and Awashti (2003) was implemented by many researchers (Voudouris, 2006; Taheri Tizro et al., 2007; Türker et al., 2013), considering water balance equation to establish the yield restrictions. Voudouris (2006) studied water balance and safe yield in coastal aquifer of Korinthia, an agrotourism center in Greece, where total abstractions are greater than the recharge and the safe yield, resulting in signs of aquifer depletion, seawater intrusion and groundwater quality contamination. The integrated water management through measures that augment the groundwater budget in the coastal aquifer was recommended. Estimating groundwater balance of the alluvial aquifer of Kangavar in west Iran confirmed current abstractions which exceed both recharge and safe yield of the aquifer system are not sustainable and the aquifer system has overexploited. Artificial recharge of the aquifer through river beds, as well as water-saving techniques such as spray and drip irrigation were proposed in order to support sustainable management of groundwater resources in this area (Taheri Tizro et al., 2007). The results of safe yield analysis for the Yeşilköy aquifer in Cyprus (Türker et al., 2013) showed that annual safe yield exceeds the natural aquifer recharge and sustainability of the aquifer is not foreseen. Decreasing groundwater abstraction by lowering the water volume for irrigation use or providing another source like seawater desalination for domestic use were recommended to attain the safe yield.

Bahabad plain is an important agricultural area in Yazd province at central Iran. Excessive groundwater withdrawals for both agricultural and industrial usages impose more stress on the aquifer, results in continuous decline of water table with an average rate of $50 \mathrm{~cm}$ annually. Depleting aquifer storage, reduction of groundwater availabilities and increase in pumping costs are the main negative possible impacts which have decreased agricultural activities in the region, enhancing migration to the neighboring cities (personal communication with local governor). Reduction of quantity of the water resources increases the concerns that the safe yield of the aquifer has been exceeded, challenging sustainable development of this arid region. Hence, the aim of this study was to assess the sustainability of groundwater resources, considering estimation of safe yield and water balance. In this regard, the roles of agricultural and industrial abstractions in depleting the aquifer storage were also examined and strategies to achieve the safe yield were discussed.

\section{Study area description}

Bahabad plain, $220 \mathrm{~km}$ far from Yazd city at central Iran (Fig. 1), locates between two parallel NE-SE highlands. The alluvial sediments of the plain are situated principally in a graben structure, where the thickness increases more than $580 \mathrm{~m}$ at the center (Yazd Regional Water Authority, 1996). The quaternary alluvial deposits include old terraces, younger terraces, fluvial sediments and salty mud flats. There is a general trend of decreasing grain size of the sediments from south to the north, following the topographic surface slope (Fig. 2).

Bahabad unconfined aquifer with an area of about $366 \mathrm{~km}^{2}$ lies between latitudes of $31^{\circ} 43^{\prime}$ and $32^{\circ} 12^{\prime} \mathrm{N}$ and longitudes of $55^{\circ} 42^{\prime}$ and $56^{\circ} 17^{\prime} \mathrm{E}$. Groundwater levels are being monthly monitored in a network of 14 piezometers (Fig. 2) since 2002. 
Bahabad aquifer is discharged by 78 pumping wells including 51 agricultural, 22 industrial and 5 municipal wells (Fig. 1), extracting the aquifer with an average annual rate of 25.5, 6.2 and 4.8 million cubic meter (MCM), respectively (Shirafkan, 2013). Three qanats in southern part are also discharging the aquifer with an average rate of

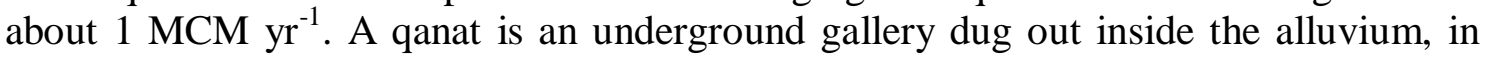
order to transfer groundwater to the ground surface by gravitation force.

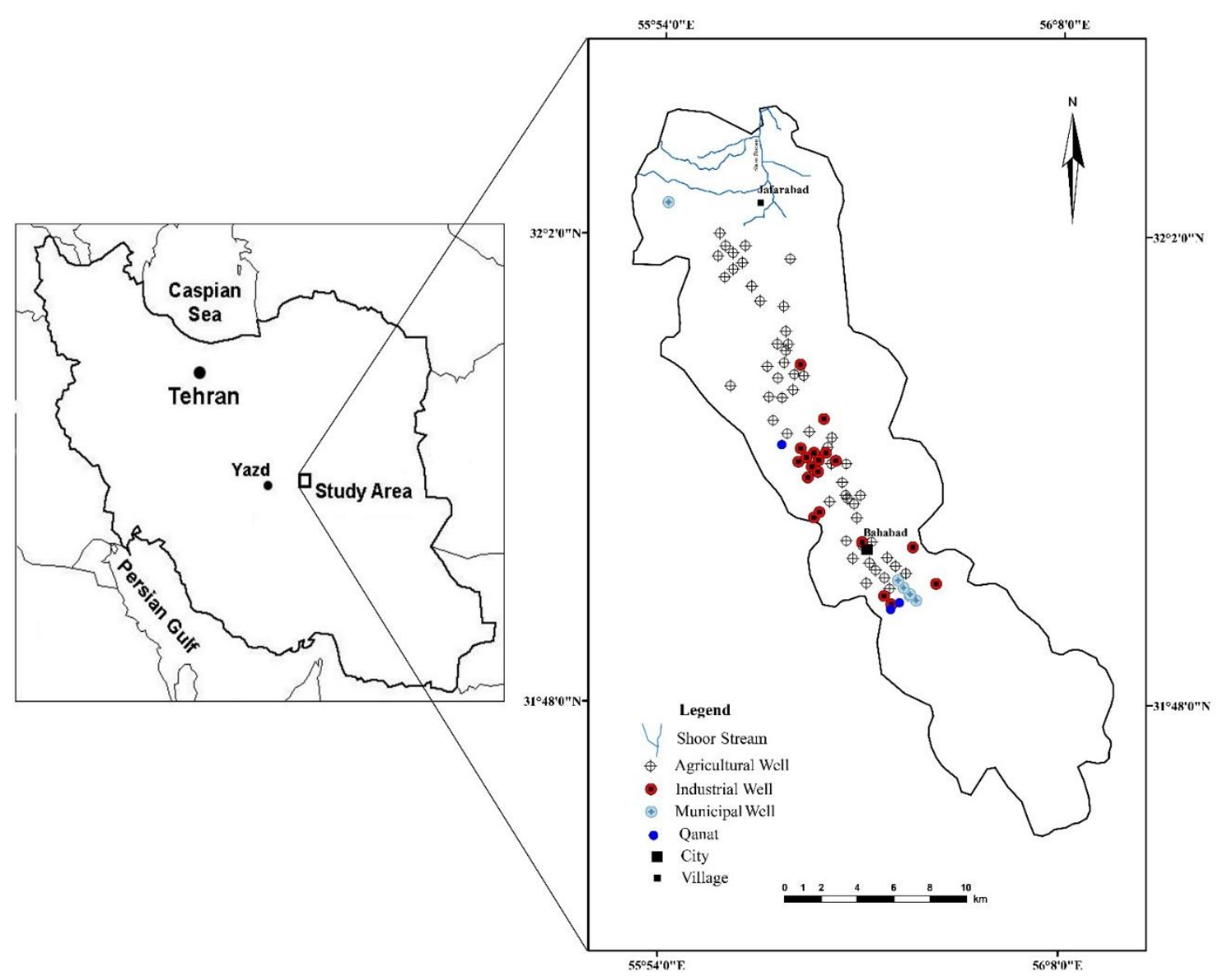

Figure 1. Map showing location of the study area and spatial distribution of the wells and qanats in the Bahabad aquifer

Based on iso-potential (contour) map of the aquifer, the groundwater flow is generally directed from south to the north (Fig. 2a). A closed depression in water table occurred at the center of the aquifer, where it is locally pumped by a well-field including 10 wells which extract groundwater for industrial uses. It must be mentioned that most of the water pumped by industrial wells is used in the Chadormalu Mining and Industrial Company which is located out of the aquifer basin, $75 \mathrm{~km}$ far from the Bahabad city. Due to the well-field abstraction, the flow lines are concentrated toward the center of the well-field and the groundwater divides at the vicinity of the piezometers P7 and P8 (Fig. 2a). It results in bisecting the aquifer system into two separated hydrological zones.

Depth to groundwater is highly decreased at the north of the plain, where the aquifer is permanently drained by the Shoor stream (Fig. 1). 

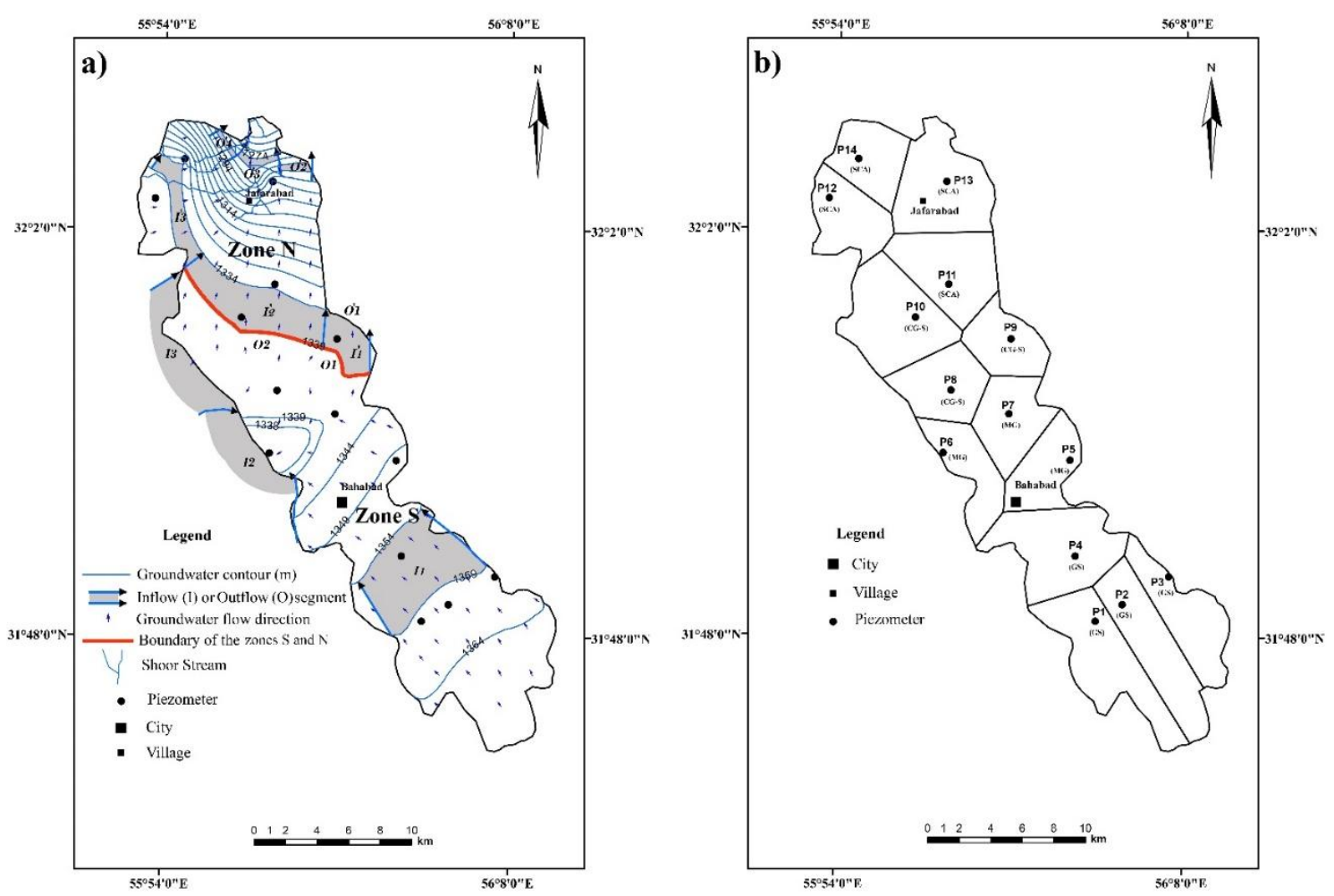

Figure 2. a) Iso-potential map of the Bahabad aquifer representing groundwater flow direction with inflow and outflow boundaries; b) Thiessen's polygons surrounding piezometers. The dominant lithology (GS: gravelly sand; MG: medium gravel, CG-S: clay-gravel and sand; SCA: silt/clay rich alluvium) is also presented

\section{Materials and methods}

\section{Groundwater Balance}

Groundwater balance is based on the comparison of the total inputs and outputs to/from the aquifer during a specified period (balance period), written as:

$$
\sum \text { Inputs }-\sum \text { Outputs }=\text { Change in aquifer storage }
$$

Considering inputs and outputs to/from the Bahabad aquifer, the following balance equation was applied:

$$
\left(G_{\text {in }}+R_{r}+I_{r f}+W_{\text {rf }}\right)-\left(G_{\text {out }}+G_{d}+G_{w}\right)= \pm \Delta V
$$

where $G_{\text {in }}$ is groundwater inflow through aquifer boundary, $R_{r}$ rainfall recharge, $I_{r f}$ return flows from irrigation, $\mathrm{W}_{\mathrm{rf}}$ recharge by municipal wastewater, $\mathrm{G}_{\text {out }}$ groundwater outflow from boundary of the aquifer, $G_{d}$ groundwater drainage into Shoor stream, $G_{w}$ groundwater withdrawal and $\Delta \mathrm{V}$ change in aquifer storage volume. All terms are expressed as volume of water during the balance period $\left(\mathrm{MCM} \mathrm{yr}^{-1}\right)$.

In addition to water balance formulation ( $E q .1)$, change in aquifer storage volume $(\Delta \mathrm{V})$ is also calculated by Equation 2 to validate the groundwater balance calculations. 


$$
\Delta \mathrm{V}=\mathrm{A} \times \mathrm{Sy} \times \Delta \mathrm{H}
$$

where $\mathrm{A}$, Sy and $\Delta \mathrm{H}$ denote aquifer area $\left(\mathrm{m}^{2}\right)$, mean specific yield of the aquifer (dimensionless) and spatially averaged rise or decline in groundwater level during balance period $(\mathrm{m})$, respectively. As the water levels are not uniform in the aquifer, the spatially monthly averaged groundwater level $(\mathrm{H})$ is calculated using Equation 3.

$$
\mathrm{H}=\sum_{i=1}^{n} \frac{(\mathrm{h})_{i} \times a_{i}}{A}
$$

where $(\mathrm{h})_{\mathrm{i}}$ is the height of groundwater table above datum (sea level) in piezometer $\mathrm{i}$ $(\mathrm{m}), \mathrm{a}_{\mathrm{i}}$ the area of the Thiessen's polygon surrounding piezometer $\mathrm{i}\left(\mathrm{m}^{2}\right)$, A the total aquifer area $\left(\mathrm{m}^{2}\right)$ and $\mathrm{n}$ the number of piezometers installed in the aquifer.

Specific yield (Sy) is defined as the ratio of the volume of water gravitationally drained, after saturation, to the total volume of the drained soil (Todd and Mayes, 2005). In the present study, Sy was determined using standard values in literatures (Johnson, 1967; Lerner et al., 1990) considering soil texture in aquifer's drilling logs. The method is generally acceptable (Fetter, 2000), employed by many researchers in areas like the study area devoid pumping test data (e.g. Obuobie et al., 2012; Lerner et al., 1990).

\section{Safe yield}

In this research the safe yield was estimated by Equation 4 adapted from Naik and Awasthi (2003). It includes all exploitable/utilizable groundwater originating within the aquifer basin, consisting exploitable dynamic groundwater reserve $\left(\mathrm{Q}_{\mathrm{ed}}\right)$, value of groundwater pumped for irrigation and other uses in wet season $\left(\mathrm{Q}_{\text {wet }}\right)$ and return flows from irrigation and sewage $\left(\mathrm{Q}_{\mathrm{rw}}\right)$. All terms are expressed as volume per time $\left(\mathrm{MCM} \mathrm{yr}^{-1}\right)$.

$$
\text { Safe yield }=Q_{e d}+Q_{w e t}+Q_{r w}
$$

The exploitable dynamic groundwater $\left(\mathrm{Q}_{\mathrm{ed}}\right)$ represents the long-term average annual recharge under conditions of maximum groundwater abstraction (dry season). Generally, maximum groundwater extraction occurs in Bahabad region when irrigation starts from beginning of the June until December. Thus, $\mathrm{Q}_{\mathrm{ed}}$ is estimated using Equation 5:

$$
\text { Qed }=\sum_{i=1}^{n} a_{i} \times(S y)_{i} \times\left(D_{l d}\right)_{i}
$$

where $(\mathrm{Sy})_{\mathrm{i}}$, and $\left(\mathrm{D}_{\mathrm{ld}}\right)_{\mathrm{i}}$ denote the specific yield (dimensionless) and the value of water level decline during the dry season (June to December) in piezometer $\mathrm{i}(\mathrm{m})$, respectively. Parameters $\mathrm{a}_{\mathrm{i}}$ and $\mathrm{n}$ were defined before in Equation 3.

Value of groundwater pumped in wet season $\left(\mathrm{Q}_{\text {wet }}\right)$ refers to the discharge mainly by agricultural and industrial wells during January to May. In this period the total recharge by the rainfall is occurred and aquifer discharge rates by agricultural wells are mostly 
diminished in response to reduction in evapotranspiration and irrigation demands. This value plus return flows from irrigation and sewage are also considered as utilizable groundwater sources in the region to calculate the safe yield.

\section{Results and discussion}

\section{Assessing groundwater balance of the Bahabad aquifer}

Regarding the impact of the industrial well-field on the groundwater flow pattern (Fig. 2a) the aquifer was divided into two hydrological zones namely as $\mathrm{N}$ and $\mathrm{S}$ and the groundwater balance in each zone was calculated for water-year 2010-2011 (starting at September 23). Based on Equation 1 the inputs and outputs to/from Bahabad aquifer were determined as the following:

\section{Inputs}

Rainfall recharge, groundwater flow through aquifer boundary and return flows from irrigation and domestic uses are the main inputs into the Bahabad aquifer.

\section{a) Rainfall recharge $\left(\mathrm{R}_{\mathrm{r}}\right)$}

Rainfall data from Bahabad climatological station at the plain center was used to determine the mean representative rainfall on the aquifer. Regarding the surface area $\left(366 \mathrm{~km}^{2}\right)$ and relatively flat topography of the aquifer, the rainfall measurements in this station are representative to the whole aquifer, as the rain-gauge density in the plains is proposed be one station per $520 \mathrm{~km}^{2}$ (Raghunath, 2009). Based on the data measured in this station for a period of 22-year (1988-2010) the depth of annual precipitation varies from 28.5 to $120.5 \mathrm{~mm}$ and the average annual rainfall of the plain is $81.5 \mathrm{~mm}$. It mainly occurs during winter (January-March) and spring (April-May) seasons.

The relationship between groundwater recharge and precipitation is governed by different factors such as type of precipitation, climatic conditions, soil moisture prior to storm, storm characteristics (duration, intensity, peak intensity), topography of ground surface, perviousness of ground surface and vegetation cover (Bear, 1979). The rainfall recharge coefficient in adjacent areas having the same climate and lithological formations to the study area was directly measured using the experimental lysimeters (Parab Fars, 2008), which varied from 5 to $10 \%$ for the fine and coarse soils, respectively (Parab Fars, 2008). Therefore, the rainfall recharge coefficient was decided to be $10 \%$ for the zone $\mathrm{N}$, which is mainly covered by sand and medium gravel sediments and $5 \%$ for the zones $\mathrm{S}$ with silt/clay rich alluviums (Fig. 2b). The annual rainfall during balance period (water-year 2010-2011 starting at September 23) was $30 \mathrm{~mm}$, then annual recharge rate to the aquifer zones of $\mathrm{S}$ and $\mathrm{N}$ was estimated as the following:

$$
\begin{gathered}
\mathrm{R}_{\mathrm{r}}=\text { Rainfall depth } * \text { Rainfall recharge coefficient } * \text { Aquifer area } \\
\mathrm{R}_{\mathrm{r}}=\left(30 * 10^{-3}\right) *(10 \%) *\left(235^{*} 10^{6}\right)=0.7 * 10^{6} \mathrm{~m}^{3} \mathrm{yr}^{-1}=0.7 \mathrm{MCM} \mathrm{yr}^{-1} \text { Zone S } \\
\mathrm{Rr}=\left(30 * 10^{-3}\right) *(5 \%) *\left(131 * 10^{6}\right)=0.2^{*} 10^{6} \mathrm{~m}^{3} \mathrm{yr}^{-1}=0.2 \mathrm{MCM} \mathrm{yr}^{-1} \text { Zone N }
\end{gathered}
$$


b) Groundwater inflow through aquifer boundary $\left(\mathrm{G}_{\mathrm{in}}\right)$

The entire inflow boundary of the aquifer was divided into segments named as $\mathrm{Ij}$ or $I$ ' $j$ where index $j$ denotes the number of the segment. The groundwater inflow through

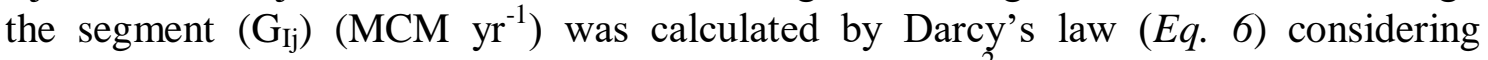
average aquifer transmissivity along the segment $\left(T_{j}\right)\left(\mathrm{m}^{2} /\right.$ day), length of the segment $(\mathrm{Wj})(\mathrm{m})$ and component of the hydraulic gradient normal to it $\left(\mathrm{i}_{\mathrm{j}}\right)(\mathrm{m} / \mathrm{m})$. Flows into the segments were summed to calculate total groundwater inflow through aquifer boundary $\left(\mathrm{G}_{\mathrm{in}}\right)\left(\mathrm{MCM} \mathrm{yr}^{-1}\right)$.

$$
\mathrm{G}_{\mathrm{in}}=\sum_{j=1}^{m}\left(G_{I_{j}}\right)=\sum_{j=1}^{m}\left(W_{j} \times T_{j} \times i_{j}\right)
$$

in which, the index m stands for the maximum number of the segments.

Three inflow segments were identified on the contour map of the groundwater surface in each of the zones $\mathrm{S}$ and $\mathrm{N}$ of the aquifer (Fig. 2a). The average transmissivity of the aquifer along the segments $\left(\mathrm{T}_{\mathrm{j}}\right)$ has only been measured by pumping test in one exploration well at the south (segment $\mathrm{I}_{1}$ ) which is about $3664.5 \mathrm{~m}^{2} / \mathrm{day}$. In other segments the transmissivity values were estimated by multiplying hydraulic conductivity, inferred from soil texture in aquifer drilling logs, and aquifer thickness (Shirafkan, 2013). It varies from 300 to $792.9 \mathrm{~m}^{2} /$ day at the center, decreases to about $5.5 \mathrm{~m}^{2} /$ day at the northern parts of the aquifer (Table 1). The decreasing trend in transmissivity values is in consistent with changes in aquifer soil texture from gravelly sand and medium gravel in south and center to silt/clay rich alluvium at the north (Fig. 2b).

Table 1. Values of groundwater inflow and outflow through boundaries of the aquifer balance areas $S$ and $N$ during water-year 2010-2011

\begin{tabular}{|c|c|c|c|c|c|}
\hline Aquifer zones & $\begin{array}{c}\text { Inflow (I) or } \\
\text { outflow }(O) \\
\text { segment }\end{array}$ & $\begin{array}{l}\text { Segment width } \\
\text { (m) }\end{array}$ & $\begin{array}{l}\text { Hydraulic } \\
\text { gradient } \\
(\mathbf{m} / \mathbf{m})\end{array}$ & $\begin{array}{l}\text { Transmissivity } \\
\left(\mathbf{m}^{2} / \text { day }\right)\end{array}$ & $\begin{array}{c}\text { Annual inflow or } \\
\text { outflow } \\
\left(\text { MCM yr }^{-1}\right)\end{array}$ \\
\hline \multirow{7}{*}{ Zone S } & $\mathrm{I}_{1}$ & 7024.5 & 0.001 & 3664.5 & 9.86 \\
\hline & $\mathrm{I}_{2}$ & 5545 & 0.002 & 792.9 & 2.82 \\
\hline & $\mathrm{I}_{3}$ & 10000 & 0.002 & 300 & 1.75 \\
\hline & \multicolumn{4}{|c|}{ Sum of groundwater inflows } & 14.4 \\
\hline & $\mathrm{O}_{1}$ & 3500 & 0.002 & 300 & 0.67 \\
\hline & $\mathrm{O}_{2}$ & 9752 & 0.002 & 300 & 2.31 \\
\hline & \multicolumn{4}{|c|}{ Sum of groundwater outflows } & 3 \\
\hline \multirow{9}{*}{ Zone N } & $\mathrm{I}_{1}$ & 3500 & 0.002 & 300 & 0.67 \\
\hline & $\mathrm{I}_{2}$ & 9752 & 0.002 & 300 & 2.31 \\
\hline & $\mathrm{I}_{3}$ & 7500 & 0.003 & 300 & 2.9 \\
\hline & \multicolumn{4}{|c|}{ Sum of groundwater inflows } & 5.9 \\
\hline & $\mathrm{O}_{1}^{\prime}$ & 3500 & 0.002 & 300 & 0.67 \\
\hline & $\mathrm{O}_{2}^{\prime}$ & 2000 & 0.006 & 5.5 & 0.03 \\
\hline & $\mathrm{O}_{3}$ & 4661.5 & 0.013 & 5.5 & 0.12 \\
\hline & $\mathrm{O}_{4}$ & 1900 & 0.016 & 5.5 & 0.06 \\
\hline & \multicolumn{4}{|c|}{ Sum of groundwater outflows } & 0.9 \\
\hline
\end{tabular}


In each segment, hydraulic gradient $\left(i_{j}\right)$ was calculated from iso-potential map of the aquifer (Fig. 2a) considering head difference $\left(\mathrm{dh}_{\mathrm{j}}\right)$ in a selected distance of $\mathrm{dl}_{\mathrm{j}}$ $\left(\mathrm{i}_{\mathrm{j}}=\mathrm{dh}_{\mathrm{j}} / \mathrm{dl}_{\mathrm{j}}\right.$ ). It varies from 0.001 to $0.003 \mathrm{~m} / \mathrm{m}$ at inflow boundaries (Table 1). The highest value are observed at inflow segment I' ${ }_{3}$ in the north of the aquifer where the slit/clay rich alluviums are dominant. Applying Equation 6, the total annual volume of groundwater entering the zones $\mathrm{S}$ and $\mathrm{N}$ of Bahabad aquifer were calculated as 14.4 and 5.9 MCM, respectively (Table 1). As a result, the main groundwater flow into the Bahabad aquifer (9.86 $\mathrm{MCM} \mathrm{yr}^{-1}$ ) is taking place through segment $\mathrm{I}_{1}$ at the south of the plain.

c) Recharge due to water returns ( $\mathrm{I}_{\mathrm{rf}}$ and $\mathrm{W}_{\mathrm{rf}}$ )

Return flow consists of a portion of the water applied for irrigation, industry and domestic uses in the region, which is not used up as "consumptive use" but infiltrates, and eventually reaches the water table. It is estimated that 63.7 and $98.5 \%$ of the total extracted groundwaters in the $\mathrm{S}$ and $\mathrm{N}$ zones of Bahabad aquifer are used for agricultural activities, respectively (Shirakan, 2013). Irrigation return flow coefficients (percent ratio of return flow to the applied irrigation water) in other areas with the same soil texture, climate and irrigation management practices were determined using lysimeters. They varied from 0.4 to $38.7 \%$ depending on the total applied water, field length, irrigation management and soil texture (Jafari et al., 2012). In the present study, irrigation return flow coefficients of 15 and $10 \%$ were decided for the zones $\mathrm{S}$ and $\mathrm{N}$, respectively. The lower value in the zone $S$ is related to the finer texture of the surface soils. The adopted values are nationally acceptable, as they are in the range applied in many groundwater budget studies around the country (Iran Water Resources Management Company, 1991).

Annual volumes of groundwater discharged by agricultural wells and qanats at the zones $\mathrm{S}$ and $\mathrm{N}$ of Bahabad aquifer are 20 and $6.5 \mathrm{MCM}$, respectively. Therefore, the annual amounts of recharge from agricultural activities were estimated at 3 and 0.6 MCM, respectively.

$$
\mathrm{I}_{\mathrm{rf}}=\text { Agricultural discharge rate * Irrigation return flow coefficient }
$$

$$
\begin{gathered}
\mathrm{I}_{\mathrm{rf}}=20 * 15 \%=3 \mathrm{MCM} \mathrm{yr}^{-1} \quad \text { Zone } \mathrm{S} \\
\mathrm{I}_{\mathrm{rf}}=6.5 * 10 \%=0.6 \mathrm{MCM} \mathrm{yr}^{-1} \quad \text { Zone } \mathrm{N}
\end{gathered}
$$

Disposal wells in the Bahabad urban and rural areas have the potential to recharge the aquifer, too. Per the norm prescribed by Iran Water Resources Management Company (1991), 50-70\% of the water used in urban areas, percolates down in shallow disposal wells and reaches the underlying aquifer. Total annual discharges by municipal wells in the zones $\mathrm{S}$ and $\mathrm{N}$ of the Bahabad aquifer are 4.7 and $0.1 \mathrm{MCM}$, respectively. Thus, annual recharge due to the return seepage from water applied for municipal uses was estimated 2.8 and $0.05 \mathrm{MCM}$, considering return coefficients of 60 and $50 \%$ in the zones $\mathrm{S}$ and $\mathrm{N}$, respectively. The difference in the coefficients is mostly related to variations in soil texture as it was discussed before. 
$\mathrm{W}_{\mathrm{rf}}=$ Municipal discharge rate $*$ Municipal return flow coefficient

$$
\begin{aligned}
\mathrm{W}_{\mathrm{rf}} & =4.7 * 60 \%=2.8 \mathrm{MCM} \mathrm{yr}^{-1} \quad \text { Zone } \mathrm{S} \\
\mathrm{W}_{\mathrm{rf}} & =0.1 * 50 \%=0.05 \mathrm{MCM} \mathrm{yr}^{-1} \text { Zone } \mathrm{N}
\end{aligned}
$$

It must be mentioned that total groundwater discharged by industrial wells in the zone $\mathrm{S}$ is transferred and consumed out of the study's aquifer area; therefore, no recharge return flow to the aquifer from industrial uses is expected.

\section{Outputs}

a) Groundwater outflow from aquifer boundary $\left(\mathrm{G}_{\text {out }}\right)$

Groundwater flows out of the aquifer balance area through segments symbolized as $\mathrm{O}$ and $\mathrm{O}^{\prime}$ in Figure 2. Same as the groundwater inflows, the values of groundwater outflows were estimated using Darcy's law (Eq. O). The values of aquifer transmissivity in outflow segments vary from 5.5 to $300 \mathrm{~m}^{2} /$ day and hydraulic gradients change from 0.002 to 0.016 (Table 1). Applying Equation 6, the total annual volumes of groundwater leaving zones $\mathrm{S}$ and $\mathrm{N}$ were estimated to be 3 and $0.9 \mathrm{MCM}$, respectively (Table 1).

b) Drainage into the Shoor stream $\left(\mathrm{G}_{\mathrm{d}}\right)$

Shoor stream with an average discharge rate of about 40 lit/s (Shirafkan, 2013) is a gaining (effluent) river which drains the Bahabad aquifer only at the northern part (zone $\mathrm{N})$. All the baseflow in the stream is derived from groundwater, as water table elevations in the vicinity of the stream are higher than the stream bed (Shirafkan, 2013). The baseflow was separated from direct runoff using straight-line method (Chow, 1988), considering lowest discharge during the year. It was estimated to be about 0.035 $\mathrm{m}^{3} / \mathrm{sec}$ (Fig. 3). So, the annual volume of groundwater drained by the Shoor stream was estimated to be about 1.1 MCM.

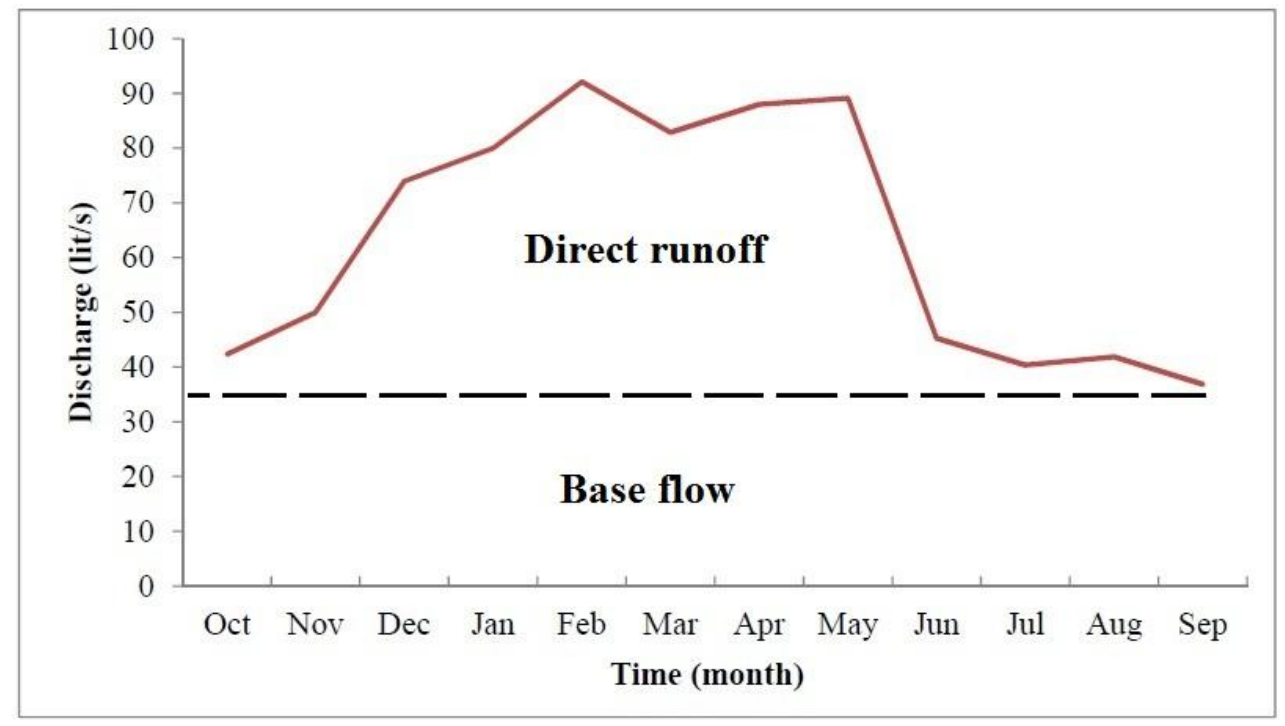

Figure 3. Mean monthly hydrograph of Shoor stream during 1992 to 2011. 


$$
\begin{gathered}
\mathrm{G}_{\mathrm{d}}=0 \quad \text { Zone } \mathrm{S} \\
\mathrm{G}_{\mathrm{d}}=0.035 \mathrm{~m}^{3} / \mathrm{sec}=1.1 \mathrm{MCM} \mathrm{yr}^{-1} \text { Zone } \mathrm{N}
\end{gathered}
$$

c) Groundwater withdrawal $\left(\mathrm{G}_{\mathrm{w}}\right)$

Water is withdrawn from Bahabad aquifer by deep and semi-deep wells and qanats. Based on measured data from Yazd regional water authority (Shirafkan, 2013), annual volume of groundwater extracted by agricultural, municipal and industrial wells, as well as, qanats in the zone $\mathrm{S}$ were 19, 4.7, 6.2 and $1 \mathrm{MCM}$, respectively. Discharge by agricultural wells in the zone $\mathrm{N}$ was 6.5 and by industrial wells was $0.10 \mathrm{MCM} \mathrm{yr}^{-1}$. No qanats and municipal wells are presented in this zone (Fig. 1). Total values of groundwater withdrawn from zones $\mathrm{S}$ and $\mathrm{N}$ of the Bahabad aquifer were calculated as below:

$\mathrm{G}_{\mathrm{w}}=$ Discharge by agricultural wells + Discharge by municipal wells + discharge by industrial wells + Discharge by qanats

$$
\begin{gathered}
\mathrm{G}_{\mathrm{w}}=19+4.7+6.2+1=30.9 \mathrm{MCM} \mathrm{yr}^{-1} \text { Zone } \mathrm{S} \\
\mathrm{G}_{\mathrm{w}}=6.5+0.1+0+0=6.6 \mathrm{MCM} \mathrm{yr}^{-1} \text { Zone } \mathrm{N}
\end{gathered}
$$

\section{Groundwater balance}

The components of groundwater balance in the $\mathrm{S}$ and $\mathrm{N}$ zones of Bahabad aquifer are presented in Table 2. The groundwater balance of the aquifer in the zones $\mathrm{S}$ and $\mathrm{N}$ was calculated by Equation 1 as the following:

$$
\begin{gathered}
(\text { Gin }+\mathrm{Rr}+\mathrm{Irf}+\mathrm{Wrf})-(\mathrm{Gout}+\mathrm{Gd}+\mathrm{Gw})= \pm \Delta \mathrm{V} \\
(14.4+0.7+3.0+2.8)-(3.0+0+30.9)=20.9-33.9=-13 \mathrm{MCM} \mathrm{yr}^{-1} \mathrm{Zone} \mathrm{S}^{-1} \text {. } \\
(5.9+0.2+0.6+0.05)-(0.9+1.1+6.6)=6.8-8.6=-1.8 \mathrm{MCM} \mathrm{yr}^{-1} \text { Zone N }
\end{gathered}
$$

Total annual outputs from $\mathrm{S}$ and $\mathrm{N}$ zones are calculated 33.9 and 8.6 MCM, exceeding the total inputs of 20.9 and $6.8 \mathrm{MCM}$, respectively. A negative groundwater balance of about 13 and 1.8 $\mathrm{MCM} \mathrm{yr}^{-1}$ was estimated for these zones during water-year 2010-2011.

In order to validate the aquifer balance calculations (Table 2), change in aquifer storage $(\Delta \mathrm{V})$ was also estimated using Equation 2, considering measured water levels in piezometers and aquifer specific yield. The values of groundwater height in each month were spatially averaged using Equation 3 and groundwater hydrographs for the zones $S$ and $\mathrm{N}$ were depicted in Figure 4 for a period of about 9-year from October 2002 to 2011. The basic data used in drawing the hydrographs are presented in the Appendix. The figure shows monthly variations of groundwater level and precipitation in the two zones of Bahabad aquifer, started at October as the first month of the water-year. 
Groundwater level has been declined about $6 \mathrm{~m}$ in the zone $\mathrm{N}$ and $4.5 \mathrm{~m}$ in the zone $\mathrm{S}$ during 2002-2011. So, the mean annual declines $(\Delta \mathrm{H})$ in the zones $\mathrm{S}$ and $\mathrm{N}$ are about 65 and $51 \mathrm{~cm}$, respectively.

Table 2. Groundwater balance at the zones $S$ and $N$ of Bahabad aquifer during water-year 2010-2011

\begin{tabular}{|c|c|c|c|}
\hline Aquifer zone & \multicolumn{2}{|c|}{ Component of water balance } & $\begin{array}{c}\text { Annual volume } \\
\left(\mathrm{MCM} \mathrm{vr}^{-1}\right)\end{array}$ \\
\hline \multirow{12}{*}{$\underline{\text { Zone } S}$} & \multirow{4}{*}{ Inputs } & Rainfall recharge & 0.7 \\
\hline & & Groundwater inflow & 14.4 \\
\hline & & Irrigation return flow & 3.0 \\
\hline & & Municipal wastewater seepage & 2.8 \\
\hline & \multicolumn{2}{|r|}{ Total inputs } & 20.9 \\
\hline & \multirow{5}{*}{ Outputs } & Groundwater outflow & 3.0 \\
\hline & & Discharge by agricultural wells & 19.0 \\
\hline & & Discharge by Qanats & 1.0 \\
\hline & & Discharge by municipal wells & 4.7 \\
\hline & & Discharge by industrial wells & 6.2 \\
\hline & \multicolumn{2}{|r|}{ Total outputs } & 33.9 \\
\hline & \multicolumn{2}{|r|}{ Inputs - outputs } & -13 \\
\hline \multirow{11}{*}{$\underline{\text { Zone } \mathbf{N}}$} & \multirow{4}{*}{ Inputs } & Rainfall recharge & 0.2 \\
\hline & & Groundwater inflow & 5.9 \\
\hline & & Irrigation return flow & 0.6 \\
\hline & & Municipal wastewater seepage & 0.05 \\
\hline & \multicolumn{2}{|r|}{ Total Inputs } & 6.8 \\
\hline & \multirow{4}{*}{ Outputs } & Groundwater outflow & 0.9 \\
\hline & & Discharge by agricultural wells & 6.5 \\
\hline & & Discharge by municipal wells & 0.1 \\
\hline & & Groundwater drainage into stream & 1.1 \\
\hline & \multicolumn{2}{|r|}{ Total outputs } & 8.6 \\
\hline & \multicolumn{2}{|r|}{ Inputs - outputs } & -1.8 \\
\hline
\end{tabular}
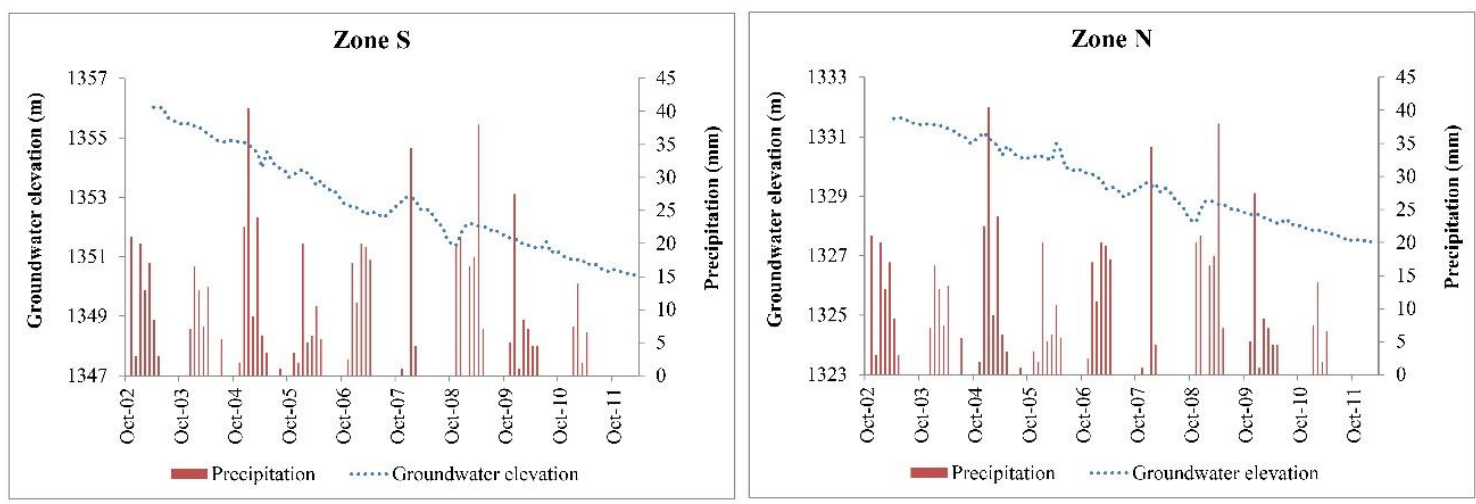

Figure 4. Groundwater hydrographs for the zones S and N of the Bahabad aquifer during 20022011 
Typical values of Sy in each piezometer were determined based on the referred standard values in literature for dominant lithology of the drilling logs (Table 3). Onethird of this laboratory measurements were considered as the field values of the Sy, because of the air entrapped near the water table, aquifer stratification and slow drainage of materials above the water table (Mcworther and Sunada, 1977). The spatially averaged values of $\mathrm{Sy}$ in the zones $\mathrm{S}$ (piezometers $\mathrm{P} 1$ to $\mathrm{P} 8$ ) and $\mathrm{N}$ (piezometers P9 to P14) were estimated to be 0.07 and 0.03 , respectively. The values are in the range accepted for most aquifers in Iran.

Table 3. Estimated values of specific yield at different locations in the Bahabad aquifer

\begin{tabular}{c|c|c|c}
\hline Piezometer & Dominant soil texture & $\begin{array}{c}\text { Laboratory measured } \\
\text { specific yield (dimensionless) }\end{array}$ & $\begin{array}{c}\text { Estimated field specific } \\
\text { yield (dimensionless) }\end{array}$ \\
\hline P1 & Gravelly sand & $0.25^{1}$ & $\mathbf{0 . 0 8 3}$ \\
\hline P2 & Gravelly sand & $0.25^{1}$ & $\mathbf{0 . 0 8 3}$ \\
\hline P4 & Gravelly sand & $0.25^{1}$ & $\mathbf{0 . 0 8 3}$ \\
\hline P5 & Gravelly sand & $0.25^{1}$ & $\mathbf{0 . 0 8 3}$ \\
\hline P6 & Medium gravel & $0.23^{1}$ & $\mathbf{0 . 0 7 7}$ \\
\hline P7 & Medium gravel & $0.23^{1}$ & $\mathbf{0 . 0 7 7}$ \\
\hline P8 & Clay-gravel and sand & $0.23^{1}$ & $\mathbf{0 . 0 7 7}$ \\
\hline P9 & Clay-gravel and sand & $0.12^{1}$ & $\mathbf{0 . 0 4}$ \\
\hline P10 & Clay-gravel and sand & $0.12^{1}$ & $\mathbf{0 . 0 4}$ \\
\hline P11 & Silt/clay rich alluvium & $(0.05-0.12)^{2} 0.08^{*}$ & $\mathbf{0 . 0 4}$ \\
\hline P12 & Silt/clay rich alluvium & $(0.05-0.12)^{2} 0.08^{*}$ & $\mathbf{0 . 0 2 7}$ \\
\hline P13 & Silt/clay rich alluvium & $(0.05-0.12)^{2} 0.08^{*}$ & $\mathbf{0 . 0 2 7}$ \\
\hline P14 & Silt/clay rich alluvium & $(0.05-0.12)^{2} 0.08^{*}$ & $\mathbf{0 . 0 2 7}$ \\
\hline
\end{tabular}

${ }^{1}$ Johnson (1967)

${ }^{2}$ Lerner et al. (1990)

*Mean

Change in groundwater storage volume was calculated as the following:

$$
\Delta \mathrm{V}=\mathrm{A} \times \mathrm{Sy} \times \Delta \mathrm{H}
$$

$$
\begin{aligned}
& \Delta \mathrm{V}=\left(235^{*} 10^{6}\right) *(0.07) *(-0.65)=-11.2 * 10^{6} \mathrm{~m}^{3} \mathrm{yr}^{-1}=-11.2 \mathrm{MCM} \mathrm{yr}^{-1} \text { Zone } \mathrm{S} \\
& \Delta \mathrm{V}=\left(131 * 10^{6}\right) *(0.03) *(-0.51)=-2.02 * 10^{6} \mathrm{~m}^{3} \mathrm{yr}^{-1}=-2.02 \mathrm{MCM} \mathrm{yr}^{-1} \text { Zone } \mathrm{N}
\end{aligned}
$$

These values are consistent with the negative balances calculated by Equation 1 (-13

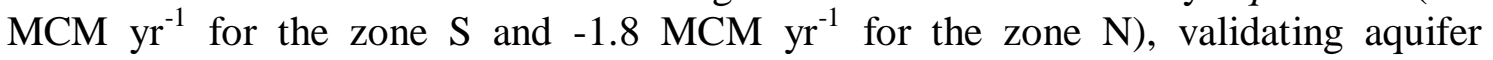
groundwater balance calculations. 
On the basis of groundwater balance study of the Bahabad aquifer in water-year 2010-2011 (Table 2), total outputs are exceeding the total inputs and the balance is negative. It confirms the aquifer system is over-drafted and the groundwater storage has diminished, notifying the current withdrawals mainly by abstraction wells are not sustainable.

\section{Safe yield}

The negative balance of the Bahabad aquifer necessitates calculation of safe yield to restrict the withdrawals at rates without detrimental effects. So, the safe yield which includes all exploitable groundwater reserves was calculated using Equation 4. In order to calculate dynamic groundwater storage $\left(\mathrm{Q}_{\mathrm{ed}}\right)$, the value of water table decline in each piezometer during dry period (June to December) was determined and presented in Table 4. It varies from 22 to $76 \mathrm{~cm}$ in the zone $S$ and 10 to $44 \mathrm{~cm}$ in the zone N. The values of Sy and area of Theissen's polygon (Fig. 2b) surrounding the piezometer (effective area) were also defined and $\mathrm{Q}_{\mathrm{ed}}$ was calculated using Equation 5. It was 6.6 $\mathrm{MCM} \mathrm{yr}^{-1}$ for the zones $\mathrm{S}$ and $1 \mathrm{MCM} \mathrm{yr}^{-1}$ for the zone $\mathrm{N}$ (Table 4).

Table 4. Dynamic groundwater storage (Qed) at the zones $S$ and $N$ of the Bahabad aquifer

\begin{tabular}{|c|c|c|c|c|c|}
\hline Aquifer zone & Piezometer & $\begin{array}{l}\text { Specific yield } \\
\text { (dimensionless) }\end{array}$ & $\begin{array}{c}\text { Effective } \\
\text { area } \\
\left(\mathbf{m}^{2}\right)\end{array}$ & $\begin{array}{c}\text { Average decline } \\
\text { of } \\
\text { water table } \\
\text { in } \\
\text { dry season (m) }\end{array}$ & $\begin{array}{c}\text { Dynamic } \\
\text { groundwater } \\
\text { storage } \\
\left(\mathbf{M C M ~ y r}^{-1}\right)\end{array}$ \\
\hline \multirow{11}{*}{ Zone S } & $\mathrm{P} 1$ & 0.08 & 35649648 & 0.37 & 1.09 \\
\hline & $\mathrm{P} 2$ & 0.08 & 30601717 & 0.22 & 0.56 \\
\hline & P3 & 0.08 & 25119927 & 0.13 & 0.27 \\
\hline & P4 & 0.08 & 35677301 & 0.41 & 1.2 \\
\hline & P5 & 0.08 & 19670291 & 0.47 & 0.71 \\
\hline & P6 & 0.08 & 19122695 & 0.57 & 0.84 \\
\hline & P7 & 0.08 & 21564947 & 0.76 & 1.3 \\
\hline & P8 & 0.04 & 21944326 & 0.38 & 0.33 \\
\hline & $\mathrm{P9}$ & 0.04 & 4826460 & 0.44 & 0.09 \\
\hline & P10 & 0.04 & 20996703 & 0.3 & 0.25 \\
\hline & \multicolumn{4}{|c|}{ Sum } & 6.6 \\
\hline \multirow{7}{*}{ Zone N } & P9 & 0.04 & 13341523 & 0.44 & 0.23 \\
\hline & P10 & 0.04 & 14342684 & 0.3 & 0.17 \\
\hline & P11 & 0.03 & 29003460 & 0.22 & 0.17 \\
\hline & $\mathrm{P} 12$ & 0.03 & 20855296 & 0.32 & 0.18 \\
\hline & P13 & 0.03 & 33940634 & 0.1 & 0.09 \\
\hline & P14 & 0.03 & 19401768 & 0.28 & 0.15 \\
\hline & \multicolumn{4}{|c|}{ Sum } & 1 \\
\hline
\end{tabular}


Volume of groundwater pumped during wet season $\left(\mathrm{Q}_{\text {wet }}\right)$ was calculated based on data from Yazd regional water authority, multiplying discharge rate and operation time of the wells. It was about 9.9 and $2.0 \mathrm{MCM} \mathrm{yr}^{-1}$ for the zones $\mathrm{S}$ and $\mathrm{N}$, respectively, generally comprises about $31-32 \%$ of the total discharge by wells and qanats in these zones.

Total volume of return flows from irrigation and sewage $\left(\mathrm{Q}_{\mathrm{rw}}\right)$ was deduced from aquifer balance calculations (Table 2). Based on the following, it was estimated to be 5.8 and $0.65 \mathrm{MCM} \mathrm{yr}^{-1}$ for the zones $\mathrm{S}$ and $\mathrm{N}$, respectively.

$$
\begin{gathered}
\mathrm{Q}_{\mathrm{rw}}=\operatorname{Irf}+\mathrm{Wrf} \\
\mathrm{Q}_{\mathrm{rw}}=3.0+2.8=5.8 \mathrm{MCM} \text { yr-1 Zone } \mathrm{S} \\
\mathrm{Q}_{\mathrm{rw}}=0.6+0.05=0.65 \mathrm{MCM} \mathrm{yr}^{-1} \text { Zone } \mathrm{N}
\end{gathered}
$$

Finally, the groundwater safe yields for the $\mathrm{S}$ and $\mathrm{N}$ zones of the Bahabad aquifer were estimated by Equation 4 as follows:

$$
\text { Safe yield }=Q_{e d}+Q_{w e t}+Q_{r w}
$$

$$
\text { Safe yield }=6.6+9.9+5.8=22.3 \mathrm{MCM} \mathrm{yr}^{-1} \text { Zone } \mathrm{S}
$$

$$
\text { Safe yield }=1.0+2.0+0.65=3.7 \mathrm{MCM} \mathrm{yr}^{-1} \text { Zone } \mathrm{N}
$$

From aforementioned estimates (Table 2), it is obvious that the total abstractions from Bahabad aquifer in the zones $\mathrm{S}\left(30.9 \mathrm{MCM} \mathrm{yr}^{-1}\right)$ and $\mathrm{N}\left(6.6 \mathrm{MCM} \mathrm{yr}^{-1}\right)$ are greater than the safe yield. Therefore, the aquifer system has been over-drafted and the groundwater mining has occurred. It proves that the sustainability of the aquifer system is not foreseen under current circumstances. Depletion of groundwater resources and deterioration of the groundwater quality and subsequent soil salinization of the agricultural lands (Zalidis et al., 2002) are the main environmental problems predicted, as a result of continued groundwater over-exploitation. In this regard, the effect of intensive groundwater abstraction by deep and semi-deep agricultural and industrial wells on storage depletion of the Bahabad aquifer is investigated in more details as follows:

Industrial abstractions: As it was previously mentioned, the pumped water by industrial wells is totally transferred out of the groundwater basin area. Therefore, no recharge by return flows from industrial uses is expected. Assuming this water is consumed on the zone $\mathrm{S}$ of Bahabad aquifer, having return flow coefficient of about 60\% (Iran Water Resources Management Company, 1991), the negative groundwater balance or aquifer budget deficit will be decreased to $9.2 \mathrm{MCM} \mathrm{yr}^{-1}$. However, change in groundwater flow pattern due to the concentrated pumping would still be occurred.

Agricultural abstractions: The specific role of agricultural discharge on depletion of the aquifer storage was investigated by assuming zero discharge for industrial wells in water balance equation. The results show the budget deficit of about $6 \mathrm{MCM} \mathrm{yr}^{-1}$ in the aquifer zone $\mathrm{S}$, drawing attention to the more significant role of agricultural abstractions 
in Bahabad aquifer depletion. This is in contrast to the public perception of considering industrial abstractions as the major cause of depletion.

\section{Conclusions and recommendations}

The sustainability of groundwater resources of the Bahabad aquifer in central Iran was evaluated by groundwater balance studies and the safe yield analyses. The aquifer is highly discharged by 78 deep and semi-deep wells for agricultural and industrial uses. A closed depression in water table which formed due to concentrated groundwater pumping by the industrial wells has changed groundwater flow patterns, dividing the aquifer system into southern $(\mathrm{S})$ and northern $(\mathrm{N})$ zones. The main inputs (rainfall recharge, inflow through aquifer boundaries, recharge due to return flow from irrigation and sewage) and outputs (outflow through aquifer boundaries, drainage into stream and groundwater withdraw) to/from the aquifer zones were estimated in water-year 20102011 (starting at September 23). The rainfall recharge as well as irrigation and municipal return flow coefficients were decided as 5-10, 10-15 and 50-60\%, respectively. The lower values are related to the zone $\mathrm{N}$ which mainly covered by silt/clay rich alluvium, as it compared with dominant lithology of gravel and sand in the zone S. As the pumping test results are so occasional (only one in the aquifer south), the values of transmissivity and specific yield of the Bahabad aquifer were determined as 5.5-3664.5 $\mathrm{m}^{2} /$ day and 3-8\%, respectively, considering aquifer drilling logs and the values prescribed in literature. The Bahabad aquifer is permanently drained by Shoor stream at the north. Baseflow separation of the stream hydrograph yields drainage volume of about $1.1 \mathrm{MCM} \mathrm{yr}^{-1}$.

On the basis of the water balance study, total inputs to the zone $\mathrm{S}$ and $\mathrm{N}$ are about 20.9 and $6.8 \mathrm{MCM} \mathrm{yr}^{-1}$, lower than the total outputs of about 33.9 and $8.6 \mathrm{MCM} \mathrm{yr}^{-1}$, respectively. Excess of outputs over inputs which is followed by a water table decline of 65 and $51 \mathrm{~cm} \mathrm{yr}^{-1}$, respectively, confirms the aquifer system has overexploited. The safe yield which consists all exploitable groundwater resources was calculated about

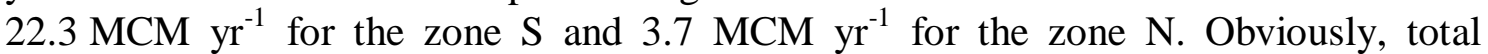
abstractions from Bahabad aquifer in the zones S (30.8 $\left.\mathrm{MCM} \mathrm{yr}^{-1}\right)$ and $\mathrm{N}\left(6.5 \mathrm{MCM} \mathrm{yr}^{-}\right.$ $\left.{ }^{1}\right)$ are greater than the safe yield. Therefore, the aquifer system is over-drafted and the groundwater mining has occurred. It proves that the sustainability of the aquifer system is not foreseen under current circumstances. The effects of intensive groundwater abstraction by deep and semi-deep agricultural and industrial wells on storage depletion of the Bahabad aquifer was investigated which highlights, in contrast to the public opinions, the important role of agricultural withdrawals.

This research clarifies the role of both industrial and agricultural abstractions in depletion of Bahabad aquifer. It is evident that the present exploitations are not sustainable and the management of this aquifer is not safe. Therefore, safe yield as a managing tool must be considered avoiding groundwater overexploitation and aquifer mining with negative consequences for the development of the region. For the aquifer system of the study area, the safe yield can be attained by a decrease in groundwater abstractions, increase in recharge or a combination of both. In order to achieve the safe yield, the following recommendations are proposed:

1. Total abstractions for use in both agricultural and industrial sectors must be reduced. In this regard improvement or change of traditional irrigation systems can be effective to reduce groundwater consumption. Industrial abstractions must be 
immediately decreased at least $50 \%$, because their values are currently about two times more than the permissible limits planned by local water authorities. In a similar international problem, management strategies including application of water-saving methods such as spray and drip irrigation were proposed to solve water balance disequilibrium of a coastal aquifer system in Greece (Voudouris, 2006).

2. Aquifer recharge must be managed by reliable methods to increase the aquifer storage. In this regard, artificial recharge projects should be developed in the region to balance the quantity of water exported for industrial uses, having no return flows to the aquifer system. Renovation of the performed projects by removing fine sediments accumulated on the surface of the recharge basins to enhance the infiltration rate is also recommended. Field tests in other places (Hionidi et al., 2002; Voudouris, 2006) confirmed the positive impacts of artificial recharge on augmentation of aquifer storage and improvement of the groundwater quality.

3. Industrial wells should be distributed throughout the aquifer system, avoiding local changes in the flow dynamics. Changes in flow direction due to the closed depression formed by industrial well-field will enhance the intrusion of the more saline groundwater of the northern part and deteriorate quality of the aquifer. An increasing trend of electrical conductivity (EC) from $3000 \mu \mathrm{mhos} / \mathrm{cm}$ to $3800 \mu \mathrm{mhos} / \mathrm{cm}$ is observed in a well located at the north of the well-field during a period of 10-year from 2001 to 2011 (Shirafkan, 2013). Other impacts such as ground settlement (Chen et al., 2003) would also be prevented.

A new research conducted in the study area after completion of the present work (Khatibinia, 2016) revealed continuity in groundwater level decreasing with a measured rate of about $0.5 \mathrm{~m} \mathrm{yr}^{-1}$. It forces immediate actions in implication of the appropriate managing strategies like mentioned above, in order to prevent groundwater mining and further depletion of the Bahabad aquifer.

Acknowledgements. The cooperation of Yazd Regional Water Authority is gratefully acknowledged. The authors wish to thank any anonymous reviewers.

\section{REFERENCES}

[1] Alley, W. M., Leake, S. A. (2004): The Journey from safe yield to sustainability. Ground Water 42(1): 12-16.

[2] Bear, J. (1979): Hydraulics of Groundwater. - McGraw-Hill, New York.

[3] Brown, L. J., Dravid, P. N., Hudson, N. A., Taylor, C. B. (1999): Sustainable groundwater resources, Heretaunga plains, Hawke's bay, New Zealand. - Hydrogeology Journal 7(5): 440-453.

[4] Central Ground Water Board (1984): Ground Water Resources of the Upper Betwa River Basin, India. - Indo-British Groundwater Project, Tech Ser., Bulletin 1. Central Ground Water Board, Ministry of Water Resources, Government of India, New Delhi.

[5] Chen, C., Pei, S., Jiao, J. (2003): Land subsidence caused by groundwater exploitation in Suzhou City, China. - Hydrogeology Journal 11(2): 275-287.

[6] Chow, V. T., Maidment, D. R., Mays, L. W. (1988): Applied Hydrology. - McGraw-Hill, New York.

[7] Fetter, C. W. (2000): Applied Hydrogeology. - Prentice Hall, Chicago

[8] Hionidi, M., Panagopoulos, A., Koumantakis, I., Voudouris, K. (2002): Groundwater quality considerations related to artificial recharge to the aquifer of the Korinthos Prefecture, Greece. - IAHS Publication: 85-90. 
[9] Iran Water resources Management Company (1991): Instruction for Preparation of Water Balance. - Ministry of Energy, Office of Water Resources Studies Report (in Persian).

[10] Jafari, H., Raeisi, E., Zare, M., Kamgar-Haghighi, A. (2012): Time series analysis of irrigation return flow in a semi-arid agricultural region, Iran. - Archives of Agronomy and Soil Science 58(6): 673-689.

[11] Johnson, A. I. (1967): Specific yield: compilation of specific yields for various materials. - US Geological Survey, Water-Supply Paper 1662-D: 74.

[12] Kalf, R. P., Woolley, D. R. (2005): Applicability and methodology of determining sustainable yield in groundwater systems. - Hydrogeology Journal 13: 295-312.

[13] Khatibinia, K. (2016): Predicting groundwater level fluctuation of Bahabad aquifer using numerical model. - MSc. Thesis, Shahrood University of Technology, Shahrood, Iran (in Persian).

[14] Lerner, D. N., Issar, A. S., Simmers, I. (1990): Groundwater recharge: a guide to understanding and estimating natural recharge. - International Contributions to Hydrogeology 8: 1-345.

[15] McWhorter, D. B., Sunada, D. K. (1977): Groundwater Hydrology and Hydraulics. Water Resources Publications, Highlands Ranch, CO.

[16] Naik, P. K., Awasthi, A. K. (2003): Groundwater resources assessment of the Koyna River basin, India. - Hydrogeology Journal 11: 582-594.

[17] Obuobie, E., Diekkrueger, B., Agyekum, W., Agodzo, S. (2012): Groundwater level monitoring and recharge estimation in the White Volta River basin of Ghana. - Journal of African Earth Sciences 71: 80-86.

[18] Parab Fars Consulting Engineering Company (2008): Studies on measurement and assessment of irrigation return flow to Harat aquifer. - Parab Fars Consulting Engineering Company Report, Shiraz, Iran (in Persian).

[19] Raghunath, H. M. (2009): Hydrology: Principle Analysis and Design. - New Age International Publishers, New Delhi.

[20] Sophocleous, M. (2000): The origin and evolution of safe-yield policies in the Kansas Groundwater Management Districts. - Natural Resources Research 9(2): 99-110.

[21] Shirafkan, M. (2013): Hydrogeology of Bahabad aquifer in Yazd province with reference to the causes of water level decline. - MSc. Thesis, Shahrood University of Technology, Shahrood, Iran (in Persian).

[22] Taheri Tizro, A., Voudouris, K. S., Eini, M. (2007): Groundwater balance, safe yield and recharge feasibility in a semi-arid environment: A case study from western part of Iran. Journal of Applied Sciences 7(20): 2967-2976.

[23] Türker, U., Alsalabi, B. S., Rizza, T. (2013): Water table fluctuation analyses and associated empirical approach to predict spatial distribution of water table at eşilköy/AgiosAndronikos aquifer. - Environmental Earth Sciences 69(1): 63-75.

[24] Todd, D. K., Mays, L. W. (2005): Groundwater Hydrology ( $3^{\text {rd }}$ ed.). - John Wiley and Sons, New York.

[25] Voudouris, K. S. (2006): Groundwater balance and safe yield of the coastal aquifer system in North Eastern Korinthia, Greece. - Applied Geography 26: 291-311.

[26] Yazd Regional Water Authority (1996): Statistical report of groundwater resources in Bahabad plain. - Ministry of Energy, Office of Water Resources Studies Report, Yazd Regional Water Authority (in Persian).

[27] Zalidis, G., Stamatiadis, S., Takavakoglou, V., Eskridge, K., Misopolinos, N. (2002): Impacts of agricultural practices on soil and water quality in the Mediterranean region and proposed assessment methodology. - Agriculture, Ecosystems \& Environment 88(2): 137-146.

[28] Zhou, Y. (2009): A critical review of groundwater budget myth, safe yield and sustainability. - Journal of Hydrology 370(1-4): 207-213. 


\section{APPENDIX}

Basic data used in drawing the groundwater hydrographs (Fig. 4)

\begin{tabular}{|c|c|c|c|c|c|c|c|c|c|c|c|c|c|}
\hline \multirow{2}{*}{ Aquifer Zone } & \multirow{2}{*}{ Water-year } & \multicolumn{12}{|c|}{ Spatially averaged water table height $(\mathrm{m})$ above mean sea level } \\
\hline & & October & November & December & January & February & March & April & May & June & July & August & September \\
\hline \multirow{10}{*}{ Zone S } & $2002-2003$ & - & - & - & - & - & - & 1356.0 & 1356.0 & 1356.0 & 1355.7 & 1355.6 & 1355.5 \\
\hline & 2003-2004 & 1355.5 & 1355.5 & 1355.5 & 1355.4 & 1355.4 & 1355.3 & 1355.1 & 1355.0 & 1354.9 & 1354.9 & 1354.8 & 1354.9 \\
\hline & $2004-2005$ & 1354.9 & 1354.9 & 1354.9 & 1354.8 & 1354.7 & 1354.5 & 1354.0 & 1354.5 & 1354.3 & 1354.0 & 1354.0 & 1353.9 \\
\hline & $2005-2006$ & 1353.7 & 1353.8 & 1353.9 & 1353.9 & 1353.8 & 1353.7 & 1353.4 & 1353.6 & 1353.3 & 1353.2 & 1353.2 & 1353.0 \\
\hline & 2006-2007 & 1352.8 & 1352.7 & 1352.7 & 1352.6 & 1352.6 & 1352.4 & 1352.5 & 1352.5 & 1352.4 & 1352.3 & 1352.5 & 1352.6 \\
\hline & $2007-2008$ & 1352.7 & 1352.9 & 1353.0 & 1353.0 & 1352.9 & 1352.6 & 1352.6 & 1352.6 & 1352.4 & 1352.1 & 1352.0 & 1351.6 \\
\hline & $2008-2009$ & 1351.5 & 1351.4 & 1351.7 & 1352.0 & 1352.1 & 1352.1 & 1352.0 & 1352.0 & 1352.0 & 1351.9 & 1351.9 & 1351.8 \\
\hline & $2009-2010$ & 1351.7 & 1351.6 & 1351.6 & 1351.5 & 1351.4 & 1351.4 & 1351.3 & 1351.3 & 1351.3 & 1351.5 & 1351.1 & 1351.2 \\
\hline & 2010-2011 & 1351.1 & 1351.0 & 1350.9 & 1350.9 & 1350.9 & 1350.9 & 1350.7 & 1350.8 & 1350.7 & 1350.6 & 1350.6 & 1350.5 \\
\hline & 2011-2012 & 1350.6 & 1350.5 & 1350.5 & 1350.4 & 1350.4 & 1350.4 & - & - & - & - & - & - \\
\hline \multirow{10}{*}{ Zone N } & $2002-2003$ & - & - & - & - & - & - & 1331.6 & 1331.6 & 1331.6 & 1331.5 & 1331.5 & 1331.4 \\
\hline & 2003-2004 & 1331.4 & 1331.4 & 1331.4 & 1331.4 & 1331.4 & 1331.3 & 1331.3 & 1331.2 & 1331.1 & 1331.0 & 1331.0 & 1330.8 \\
\hline & 2004-2005 & 1330.9 & 1331.0 & 1331.1 & 1330.9 & 1330.8 & 1330.7 & 1330.4 & 1330.7 & 1330.5 & 1330.4 & 1330.3 & 1330.3 \\
\hline & 2005-2006 & 1330.3 & 1330.3 & 1330.4 & 1330.3 & 1330.3 & 1330.2 & 1330.8 & 1330.6 & 1330.0 & 1329.9 & 1329.9 & 1329.9 \\
\hline & 2006-2007 & 1329.8 & 1329.8 & 1329.8 & 1329.6 & 1329.6 & 1329.3 & 1329.3 & 1329.3 & 1329.1 & 1329.0 & 1329.1 & 1329.2 \\
\hline & $2007-2008$ & 1329.3 & 1329.4 & 1329.4 & 1329.3 & 1329.4 & 1329.2 & 1329.3 & 1329.2 & 1329.0 & 1328.8 & 1328.7 & 1328.4 \\
\hline & 2008-2009 & 1328.2 & 1328.1 & 1328.6 & 1328.8 & 1328.9 & 1328.8 & 1328.7 & 1328.7 & 1328.6 & 1328.6 & 1328.6 & 1328.5 \\
\hline & 2009-2010 & 1328.4 & 1328.4 & 1328.4 & 1328.4 & 1328.3 & 1328.3 & 1328.2 & 1328.1 & 1328.1 & 1328.3 & 1328.0 & 1328.1 \\
\hline & 2010-2011 & 1328.0 & 1328.0 & 1327.9 & 1327.9 & 1327.9 & 1327.9 & 1327.8 & 1327.7 & 1327.7 & 1327.6 & 1327.6 & 1327.5 \\
\hline & 2011-2012 & 1327.6 & 1327.5 & 1327.5 & 1327.5 & 1327.4 & 1327.4 & - & - & - & - & - & - \\
\hline
\end{tabular}

\begin{tabular}{|c|c|c|c|c|c|c|c|c|c|c|c|c|}
\hline \multirow{2}{*}{ Water-year } & \multicolumn{12}{|c|}{ Precipitation depth (mm) } \\
\hline & October & November & December & January & February & March & April & May & June & July & August & September \\
\hline $2002-2003$ & 0 & 21 & 3 & 20 & 13 & 17 & 8.5 & 3 & 0 & 0 & 0 & 0 \\
\hline 2003-2004 & 0 & 0 & 7 & 16.5 & 13 & 7.5 & 13.5 & 0 & 0 & 5.5 & 0 & 0 \\
\hline 2004-2005 & 0 & 2 & 22.5 & 40.5 & 9 & 24 & 6 & 3.5 & 0 & 0 & 1 & 0 \\
\hline $2005-2006$ & 0 & 3.5 & 2 & 20 & 5 & 6 & 10.5 & 5.5 & 0 & 0 & 0 & 0 \\
\hline 2006-2007 & 0 & 2.5 & 17 & 11 & 20 & 19.5 & 17.5 & 0 & 0 & 0 & 0 & 0 \\
\hline 2007-2008 & 0 & 1 & 0 & 34.5 & 4.5 & 0 & 0 & 0 & 0 & 0 & 0 & 0 \\
\hline 2008-2009 & 0 & 20 & 21 & 0 & 16.5 & 18 & 38 & 7 & 0 & 0 & 0 & 0 \\
\hline 2009-2010 & 0 & 5 & 27.5 & 1 & 8.5 & 7 & 4.5 & 4.5 & 0 & 0 & 0 & 0 \\
\hline 2010-2011 & 0 & 0 & 0 & 7.5 & 14 & 2 & 6.5 & 0 & 0 & 0 & 0 & 0 \\
\hline 2011-2012 & - & - & - & - & - & - & - & - & - & - & - & - \\
\hline
\end{tabular}

